\title{
Comparative Analysis of the Domestic and Foreign Public Sports Installations and Facilities Management
}

\author{
Wang Qin,Yan Chaobing \\ The P.E Department of Jiujiang University, Jiujiang 332005, China \\ Yan8085@126.com
}

\begin{abstract}
In order to understand the domestic and foreign public sports facilities operation and management situation, existing problems, explore the mode and path of the reform of management system, project group on the basis of a large collection of relevant domestic and foreign literature, the expert interview, on-the-spot investigation and other forms, to the domestic and foreign public sports facilities management mode and comparative analysis of survey research.

Index Terms - Sports facilities, Management model, Sports industry.
\end{abstract}

\section{Introduction}

Public infrastructure for the social production, consumption and provide for the common production conditions and common circulation conditions, is not only for material production and provides general condition for people's life and public facilities. Public sports facilities as an important part of public infrastructure, is not only the people exercise venue of choice, but also an important symbol of a city's economic and cultural development, but also reflects the creation of advanced city name card. With the social development and people's health awareness, sports facilities in the status of the social resources gradually.

The urbanization and the host major sports events create great stadium, now, every city basically have built more than one large sports center, but the survey found, operation and management of the large sports facilities are not ideal, how to draw lessons from the advanced experience at home and abroad, to change the current of our public sports facilities business model, so that the effective management of operation, truly, is important topic in front of all sports facilities manager.

\section{Comparison of the investment and financing mode of sports facilities}

At present, domestic and foreign to the public sports facilities construction projects of common financing mode PPP (Public-Private-Partnership) model, ABS (Assert-BackedSecuritization) model, BOT (Build-Operate-Transfer) model, TOT (Transfer-Operate-Transfer) model. These financing although each have advantages, but because of their different application conditions, to adapt to the environment is different, and the commitment of the government role played in them, the risk and cost is not the same. We list the characteristics, financing effect and scope of application are compared. (see Table I)
TABLE I Comparison of public sports facilities financing way

\begin{tabular}{|l|l|l|l|l|}
\hline Comparison other & PPP & ABS & BOT & TOT \\
\hline Financing difficulty & More easily & Hard & Hard & Easily \\
\hline Project ownership & Some have & Don't have & possess & $\begin{array}{l}\text { May be patial } \\
\text { or total loss }\end{array}$ \\
\hline $\begin{array}{l}\text { The right to operate } \\
\text { the project }\end{array}$ & Some have & possess & Lose (to you) & $\begin{array}{l}\text { May be partial } \\
\text { or total loss }\end{array}$ \\
\hline Financing cost & Ordinary & lowest & highest & ordinary \\
\hline Financing time & Short & longer & longest & ordinary \\
\hline risk appraisal & Ordinary & minimum & maximum & ordinary \\
\hline $\begin{array}{l}\text { The macroeconomic } \\
\text { effects }\end{array}$ & Lucrative & lucrative & Pros and cons & Lucrative \\
\hline
\end{tabular}

Contrast analysis, PPP model is more suitable for the construction of policy and public welfare of public sports facilities in the project. Public sports facilities also have profit, but also not to profit for the purpose, by comparison, construction of public sports facilities in the project more suitable for the use of PPP pattern, this kind of projects have cash inflows, also cannot achieve a balanced budget. Therefore the government needs to give the necessary policy and certain financial compensation for the construction of public sports facilities, at the same time, the government also to this kind of project has stronger regulation ability.

From the investment point of view, public sports facilities in foreign countries are usually divided into for-profit and nonprofit facilities facilities two categories. Non-profit sports facilities mainly community stadium, activity center, its small size, facilities management is relatively easy, is mainly convenient community people use, improve the utilization rate, the more inclined to the "management", rather than "operation". The second is a for-profit public sports facilities, the nonprofit sports facilities, the scale is more tend to be larger, more distinctive characteristics. For example, the United States Houston Toyota Center, sports center, mainly for the purpose of profit, its management reflects the "system" of "professional". Because of the different social system at home and abroad, foreign public sports facilities construction model and our public sports facilities on the contrary. In our country, city of the large sports facilities are government funded the construction, and the public and non-profit, characteristics. On the one hand, backward sports facilities, rigid management system cannot meet the needs of the masses to participate in the public physical training needs; on the other hand, with the profit of sports facilities is small in scale, complete facilities, advanced enterprise management, such as brand fitness club, fitness clubs and other community. 


\section{Public sports facilities management system}

Different countries have used for public sports facilities management system is different, at the same time, with the continuous development of society, economy, culture, adopted in different periods have different management system. Our country is in the period of rapid development of the socialist market economy, especially after entering World Trade Organization, China's economic growth rate faster, all aspects of synchronization with the world, it can highlight the management and operation of China's large public sports facilities not only to meet the present stage of China's development needs, but also consistent with the development the world trend of public sports facilities.

At present, at home and abroad for more business and management mode of public sports facilities, in accordance with the classification methods can be summed up eleven kinds of management modes, summarizes their advantages and disadvantages are analyzed. (see Table $\Pi$ )

From the "list of" advantages and disadvantages of public sports facilities management system can be found, each kind of management methods are not perfect, have their own advantages and disadvantages, their respective scope of application, environment is different, and has a certain timeliness. Foreign public sports facilities operation and management started relatively early, and development is relatively mature, according to the different scale use of public sports facilities management system is different, the usual practice is: large sports facilities with management and administration system completely enterprises; small and medium-sized public sports facilities are more is the government agency management system. Of course, the operation and management mode is not under any circumstances can use pure market, the use of this model requires a solid economic foundation and stable as the basis, at the same time with the liberal policy environment, a wide range of market demand conditions. Present throughout our public sports facilities construction and development, the mainland first big city and coastal city has a solid economic foundation, a high per capita income, ordinary people to take part in leisure sports enthusiasm high, condition of policy environment is relatively stable open, create good environment foundation for the reform of public sports facilities in the management system of enterprise. In order to better serve the enterprise operation and management system advantages, avoid excessive lead the market development of public sports facilities and lack of public welfare and social benefits, in the beginning of reform should be established for the laws and regulations of public sports facilities in public security, from the system to avoid their own risk management system.
TABLE II The public sports facilities management system advantages and disadvantages

\begin{tabular}{|c|c|c|c|}
\hline Classification & \begin{tabular}{|l}
$\begin{array}{l}\text { Management } \\
\text { style }\end{array}$ \\
\end{tabular} & Virtue & Insufficient \\
\hline \multirow{3}{*}{$\begin{array}{l}\text { The operation } \\
\text { mechanism of } \\
\text { capital }\end{array}$} & $\begin{array}{l}\text { Full budget } \\
\text { management }\end{array}$ & $\begin{array}{l}\text { To provide adequate financial } \\
\text { support in the early stage of } \\
\text { the construction and } \\
\text { development of public sports } \\
\text { facilities, to promote the rapid } \\
\text { development of infrastructure } \\
\text { construction }\end{array}$ & $\begin{array}{l}\text { The national } \\
\text { finance burden; } \\
\text { lack of motivation; } \\
\text { operation and } \\
\text { management cost } \\
\text { is high }\end{array}$ \\
\hline & $\begin{array}{l}\text { budget } \\
\text { management by } \\
\text { remainder }\end{array}$ & $\begin{array}{l}\text { The effective control of the } \\
\text { management cost; } \\
\text { construction and maintenance } \\
\text { funds can be diversified, part } \\
\text { of reducing the government's } \\
\text { financial burden }\end{array}$ & $\begin{array}{l}\text { Easy to produce } \\
\text { facilities diversion } \\
\text { "deformation"; } \\
\text { easy to produce } \\
\text { false financial } \\
\text { appropriation } \\
\end{array}$ \\
\hline & $\begin{array}{l}\text { Money } \\
\text { management }\end{array}$ & $\begin{array}{l}\text { Save the management cost, } \\
\text { improve the utilization of the } \\
\text { funds; give full play to the } \\
\text { advantages of capital } \\
\text { diversification, to attract } \\
\text { domestic and foreign capital }\end{array}$ & $\begin{array}{l}\text { Prone to state- } \\
\text { owned asset loss or } \\
\text { damage }\end{array}$ \\
\hline \multirow{4}{*}{$\begin{array}{l}\text { Authorities } \\
\text { attribute }\end{array}$} & $\begin{array}{l}\text { The management } \\
\text { of government } \\
\text { departments }\end{array}$ & $\begin{array}{l}\text { Policy environment is good, } \\
\text { strong implementation } \\
\text { capacity }\end{array}$ & $\begin{array}{l}\text { For sports } \\
\text { understanding } \\
\text { different, easily in } \\
\text { the specific } \\
\text { matters in trouble } \\
\end{array}$ \\
\hline & $\begin{array}{l}\text { Sports } \\
\text { Management }\end{array}$ & $\begin{array}{l}\text { Familiar with the sports } \\
\text { affairs, make up for the } \\
\text { deficiency of government } \\
\text { management }\end{array}$ & $\begin{array}{l}\text { The lack of } \\
\text { flexibility, } \\
\text { enthusiasm }\end{array}$ \\
\hline & $\begin{array}{l}\text { Corporate } \\
\text { management }\end{array}$ & $\begin{array}{l}\text { Management system, } \\
\text { conditions and requirements } \\
\text { are specific, clear for } \\
\text { management, professional }\end{array}$ & $\begin{array}{l}\text { The breeding } \\
\text { behavior of short- } \\
\text { term profit, more } \\
\text { difficult to } \\
\text { guarantee the } \\
\text { public welfare of } \\
\text { public sports } \\
\text { facilities }\end{array}$ \\
\hline & $\begin{array}{l}\text { Personal } \\
\text { management }\end{array}$ & $\begin{array}{l}\text { Management system, } \\
\text { conditions and requirements } \\
\text { are specific, clear for } \\
\text { management }\end{array}$ & $\begin{array}{l}\text { The public welfare } \\
\text { and social benefit } \\
\text { is poorer; } \\
\text { specification is } \\
\text { poor and safety }\end{array}$ \\
\hline \multirow{3}{*}{$\begin{array}{l}\text { The } \\
\text { properties of } \\
\text { operators }\end{array}$} & $\begin{array}{l}\text { Complete } \\
\text { business } \\
\text { management }\end{array}$ & $\begin{array}{l}\text { Centralized management, } \\
\text { strong penetration force }\end{array}$ & $\begin{array}{l}\text { Lack of } \\
\text { enthusiasm of the } \\
\text { staff; the } \\
\text { responsibility, } \\
\text { right, Lee } \\
\text { unknown venue } \\
\text { utilization rate is } \\
\text { insufficient } \\
\end{array}$ \\
\hline & $\begin{array}{l}\text { Double-track } \\
\text { management } \\
\text { business and } \\
\text { enterprise }\end{array}$ & $\begin{array}{l}\text { Effective improve the usng } \\
\text { rate; the relationship between } \\
\text { the responsibility, right, Lee } \\
\text { clearly; effectively mobilize } \\
\text { the enthusiasm of the staff }\end{array}$ & $\begin{array}{l}\text { Has timeliness, } \\
\text { particularity, not } \\
\text { suitable for long- } \\
\text { term development } \\
\text { needs } \\
\end{array}$ \\
\hline & $\begin{array}{l}\text { Complete } \\
\text { enterprise } \\
\text { management }\end{array}$ & $\begin{array}{l}\text { Management more } \\
\text { professional; responsibility, } \\
\text { right, benefit between } \\
\text { independent, clear; venues } \\
\text { utilization rate is high; can } \\
\text { fully mobilize the enthusiasm } \\
\text { of the staff }\end{array}$ & $\begin{array}{l}\text { Public sports } \\
\text { facilities severely } \\
\text { damaged }\end{array}$ \\
\hline
\end{tabular}

\section{Public sports facilities management content}

In foreign countries, operation and management of public sports facilities is a complex system, management usually through three aspects: one is the construction and management of public sports facilities; two is the public sports facilities 
daily operation and management; three is the operation and management of sports events. (see Table III)

TABLE III Foreign public sports facilities operation and management system

\begin{tabular}{|c|c|c|}
\hline $\begin{array}{l}\text { One class } \\
\text { index }\end{array}$ & Two level index & Three level index \\
\hline \multirow{4}{*}{$\begin{array}{l}\text { Construction } \\
\text { management }\end{array}$} & $\begin{array}{l}\text { Demonstration of } \\
\text { necessity }\end{array}$ & $\begin{array}{l}\text { The participation of the masses demand; } \\
\text { impact on the local economy }\end{array}$ \\
\hline & Feasibility study & $\begin{array}{l}\text { The law support; location; quality assurance; } \\
\text { capital; reasonable planning and design; how } \\
\text { to manage }\end{array}$ \\
\hline & Planning and design & $\begin{array}{l}\text { Function idea; renovation or new; structural } \\
\text { layout, the audience area humanization, layout, } \\
\text { the venue media layout designer concept; } \\
\text { difference; construction and supervision }\end{array}$ \\
\hline & $\begin{array}{l}\text { Management of the } \\
\text { implementation process } \\
\text { of building }\end{array}$ & $\begin{array}{l}\text { The contractor selection, standard contract, } \\
\text { design, construction supervision, adjust the } \\
\text { rational use of funds }\end{array}$ \\
\hline \multirow{5}{*}{$\begin{array}{l}\text { Daily } \\
\text { management }\end{array}$} & $\begin{array}{l}\text { Management } \\
\text { mechanism }\end{array}$ & $\begin{array}{l}\text { Management structure; the personnel structure } \\
\text { and division of labor }\end{array}$ \\
\hline & $\begin{array}{l}\text { Formulate management } \\
\text { measures }\end{array}$ & $\begin{array}{l}\text { Relevant staff; the daily management of the } \\
\text { large-scale event management }\end{array}$ \\
\hline & $\begin{array}{l}\text { Advertisements } \\
\text { published in }\end{array}$ & $\begin{array}{l}\text { Advertising; advertising display advertisers } \\
\text { choice }\end{array}$ \\
\hline & Image design & $\begin{array}{l}\text { Media publicity, image design, the ability to } \\
\text { deal with emergencies }\end{array}$ \\
\hline & routine maintanance & $\begin{array}{l}\text { Infrastructure maintenance; equipment } \\
\text { maintenance; safety facilities maintenance }\end{array}$ \\
\hline \multirow{7}{*}{$\begin{array}{l}\text { Event } \\
\text { management }\end{array}$} & $\begin{array}{l}\text { Management } \\
\text { mechanism }\end{array}$ & $\begin{array}{l}\text { Management mechanism; the Organizing } \\
\text { Committee; }\end{array}$ \\
\hline & Event planning & $\begin{array}{l}\text { Event planning, division of labor and } \\
\text { cooperation, personnel regularly }\end{array}$ \\
\hline & The sale of tickets & Ticket, price setting \\
\hline & The event & $\begin{array}{l}\text { Preparation; logistics activities of the } \\
\text { organization }\end{array}$ \\
\hline & $\begin{array}{l}\text { In dealing with } \\
\text { emergencies }\end{array}$ & Stomp, fight, not civilized behavior \\
\hline & Safety and security & $\begin{array}{l}\text { Security posts; group counseling; emergency } \\
\text { disposal }\end{array}$ \\
\hline & $\begin{array}{l}\text { Commodity } \\
\text { management }\end{array}$ & $\begin{array}{l}\text { Specification for small commodities business } \\
\text { projects, property management }\end{array}$ \\
\hline
\end{tabular}

In China, operation and management of public sports facilities also has content system more complex, but our public sports facilities are usually do is "business", the operation and management of daily attention most concentrated in the facilities, so in our public sports facilities management mainly includes two aspects: one is the management; two is the property management. (see TableIV)

It is not difficult to see that in the comparison of public sports facilities in domestic and international business and content management system, operation and management of foreign public sports facilities is more systematic and perfect, content is divided to highlight details, focus on practical, focuses on the planning and management of large public sports facility, the large-scale sports events operation is just a. Be from "planning - Construction - operation" the trinity system into account, completely by the person responsible for the project to decide whether to build, function facilities, operation of the project settings, the late management etc.. But in our country, large and medium-sized public sports facilities for the government funded the construction, one part is used to satisfy various kinds of international, domestic sports demand, the other part to meet the city layout, improve the cultural atmosphere of the city, which has few considering the operating problems later these large facilities, resulting from the beginning number of functional defects in design, can not be good to meet the development of the future of public sports facilities in operation.

TABLEIV Of our public sports facilities management and content management system

\begin{tabular}{|l|l|l|}
\hline One class index & Two level index & Three level index \\
\hline \multirow{4}{*}{$\begin{array}{l}\text { operating } \\
\text { management }\end{array}$} & $\begin{array}{l}\text { Management } \\
\text { mechanism }\end{array}$ & $\begin{array}{l}\text { Personnel management positions; the division } \\
\text { of responsibilities }\end{array}$ \\
\cline { 2 - 4 } & operation control & $\begin{array}{l}\text { Engaged in project selection; member } \\
\text { management; large-scale event activities } \\
\text { organization; the daily cleaning and security; } \\
\text { financial management }\end{array}$ \\
\cline { 2 - 4 } $\begin{array}{l}\text { estate property } \\
\text { management }\end{array}$ & $\begin{array}{l}\text { venture } \\
\text { management }\end{array}$ & $\begin{array}{l}\text { Risk management procedures; group } \\
\text { counseling; emergency treatment }\end{array}$ \\
\hline management & $\begin{array}{l}\text { Water supply and drainage system; power } \\
\text { supply system; heating system; air } \\
\text { conditioning system; fire alarm system; sound } \\
\text { system, lift system, Kangle leisure equipment; } \\
\text { site equipment maintenance }\end{array}$ \\
\hline & $\begin{array}{l}\text { Facilities } \\
\text { management locker room, toilet; bath; massage; bar; } \\
\text { catering; store }\end{array}$ \\
\hline
\end{tabular}

\section{Conclusions and suggestions}

\section{A. Conclusion}

1) PPP mode is more suitable for the construction of public sports facilities projects in China;

2) The domestic and foreign public sports facilities management model has its own advantages and disadvantages in the process of management, the main consideration is to establish and perfect the management system;

3) Abroad on public sports facilities management details considerate, more consideration to the facilities after the completion of the operation, and domestic in the management content construction and foreign gap.

\section{B. Suggest}

1) The operation mode of the system of thought, must be established in accordance with the national development requirements, suitable for the local actual development situation, with vision, macro, substantive theory system.

2) Expansion of construction financing way, the introduction of PPP model, to attract private capital.

3) Clear management system, enhance the function of sports facilities.

4) Cultivation of public sports facilities management professional, strengthen the theory research.

\section{References}

[1] Tan Jianxiang. Theoretical and practical investigation on system reformation of large and medium-sized public stadium. 2010 China International Sporting Goods Fair and the sports industry and sports goods industry, 2010,5

[2] Bi Hongxing. Research on the advanced experience of foreign developed countries public sports facilities layout. Inner Mongolia Sport Science and technology,2012(1)

[3] Zheng Haohua. Development and construction of sports facilities in foreign community. Journal of Architecture,2008(1) 